\title{
EPISTEMIC MODALITY IN THE SPEECH OF RUSSIAN YOUNG CHILDREN AND ADOLESCENTS
}

\author{
Victoria V. Kazakovskaya \\ Institute for Linguistic Studies (Russian Academy of Sciences)
}

\begin{abstract}
This paper considers the early and later stages of the acquisition of epistemic modality, focusing on certainty and uncertainty, and such basic forms of their expression as parenthetical modal words (e.g. navernoe 'probably', možet byt' 'maybe', konečno 'of course', dejstvitel'no 'really'), along with sentential complement constructions (e.g. I dumaju/sčitaju, (čto) p 'I think/believe (that) p'), which are closely connected in semantics and functions. Epistemic and - more broadly - subjective (modus) markers are interpreted as linguistic tools, conveying the propositional attitudes and feelings of the speaker/writer to a given state of affairs. Sequences in the development of epistemic repertoire, the epistemic density of spoken speech and the written texts of Russian children and adolescents, as well as the functions performed by epistemic markers, both at utterance level and text level, are discussed.
\end{abstract}

Keywords: (Un)certainty, propositional attitudes, epistemic markers, early and late language development, oral and written language, Russian

\section{Introduction}

The study is devoted to the early and late stages of the development of epistemic modality in Russian language acquisition, taking into consideration the meanings of certainty and uncertainty and their basic means of expression, i.e., epistemic markers (EM). 


\section{I.I. THE NOTION OF EPISTEMIC MODALITY}

\section{AND ITS BASIC LINGUISTIC DEVICES IN RUSSIAN}

Together with the deontic and dynamic domains, epistemic modality is included in the sphere of linguistic modality, which in many languages is intended to express the speaker's propositional attitude to what is being reported (e.g., Bybee, Fleishman (eds) 1995; Palmer 2001; Boye 2016). Epistemic modality is a semantic category that reveals information about the speaker/writer - their point of view or opinion towards a given state of affairs. According to the theory of modus proposed by Ch. Bally (1965), each utterance has an objective (dictum, or proposition $-p$ ) and a subjective (modus) semantic sphere. Epistemic modality belongs to the modus part of utterance, i.e., to the subjective sphere of semantic structure (or so-called modus frame) which contrasts with the dictum part.

In Russian, the main (prototypical) EM are parenthetical modal words like naverno(e) 'probably', vidimo 'apparently', konečno 'of course', dejstvitel'no 'really' (Vinogradov 1947, Švedova (ed.) 2005). Sentential complement constructions with mental and speech verbs such as dumat' 'think', znat' 'know', sčitat' 'believe, consider', pomnit' 'remember', govorit' 'speak' (e.g. I dumaju/sčitaju, (čto) p 'I think/believe (that) p') fulfill the same functions (Tomasello 2003: 249 among others), cf.: On, navernoe, pridet zavtra 'He will probably come tomorrow' - I dumaju, čto on pridet zavtra 'I think that he will come tomorrow'. The parenthetical modal words, along with sentential complement constructions (or complex sentences with a dependent clause under the scope of a main clause expressing the speaker's judgment), might be interpreted as reduced and non-reduced (full), respectively, modus frames. Epistemic semantics belongs to the mental modus (knowledge, opinion, thinking, evaluation), reflecting the connection between the speaker and their judgment to a greater extent in comparison with other modus spheres speech, emotional, perceptual and volitional (Arutjunova 1988). 


\section{I.2. EPISTEMIC MODALITY IN FIRST LANGUAGE ACQUISITION: SOME FINDINGS}

Epistemic evaluation in child speech (CS) begins to develop quite early, though later than deontic modality (Hickmann, Bassano 2016; Stephany, Aksu-Koç (eds), in press). Thus, the initial sequence in the acquisition of modality appears to be a movement from the deontic domain to the epistemic. The somewhat later development of epistemic modality is explained by its cognitive complexity, namely, the explication of the speaker's "subjective attitudes" (Aksu-Koç 1988: 14) towards the reported matter. Revealing a speaker as the author of the probability assessment, first EM appear in early CS in anticipation of understanding (or feeling) the other's point of view (Kazakovskaya 2017, 2019).

Epistemic modality is associated with cognitively complex categories as it reflects the mental activity of a speaker, along with their verbal reflection. The acquisition of epistemic modality assumes some cognitive prerequisites associated, in particular, with the theory of mind (e.g., Papafragou 2002), and it is based on the modal input received by children which contains not only the above-mentioned EM, but also such special linguistic tools as modus questions like Kak ty dumaješ/sčitaješ, p? 'How do you think/believe p?' (Kazakovskaya 2019). These questions are related to the development of subjective (epistemic) attitudes of the child in relation to situations they describe and the ideas they express. According to recent studies, modal input, as well as child-directed speech (CDS) in general, varies significantly in terms of its quality and quantity in families of different socio-economic status (SES).

The similar tendency in the movement from the deontic domain to the epistemic in the written speech of three age groups (gradeschoolers, high-school students and adult university students) was demonstrated by J. Reilly and colleagues (2002) based on English, French and Hebrew data supplemented by Spanish examples. R. Berman (2004), discussing the findings of the research of later language 
development, considers adolescence as "a turning point" in cognitive and linguistic spheres, and calls the contemporary studies in this sphere "a burgeoning domain". In addition, the author defines some "lacunae", particularly, the investigation of oral interactive communication of adolescents, the role of language and literacy among adolescents from different SES and the clinical, and the pedagogical implications of research on adolescents with language-learning disabilities (Berman 2017: 9). Increase in the amount of the data under observation with the addition of data from different languages could also be included in a number of these tasks.

\section{I.3. EPISTEMIC MODALITY IN RUSSIAN CS}

The acquisition of epistemic modality in Russian - in the early and later stages - has to date been little investigated. A few references to this process, based mostly on diary data, can be found in Gvozdev (1949), Stoljarova (1992), Švec (2007), and Kazakovskaya (2019). These studies do not contain any examination of CDS. The first experimental studies of epistemic modality in CS of older Russian children $(6 ; 0,8 ; 0,10 ; 0)$ are those by Ovčinnikova et al. (1999) and Krauze (2004) $)^{1}$. Selected facets of early epistemic modality in developmental and cross-linguistic perspectives based on the data of typologically different Russian, Estonian and Hebrew languages are analyzed in Kazakovskaya, Argus (2016), and Kazakovskaya et al. (2018). The first studies of EM in the written speech of Russian adolescents have started (Kazakovskaya, Gavrilova 2019; Kazakovskaya, Onipenko, in press).

An overview of previous investigations of the development of epistemic modality in Russian CS is given in (Kazakovskaya in press). 


\section{I.4. HYPOTHESIS, AIMS AND RESEARCH QUESTIONS}

With age, we would expect a developmental shift towards more cognitively complex epistemic and - more widely - subjective attitudes, relating to the state of affairs reported, as well as predicting a considerable increase in the number of appropriate linguistic devices in the oral and written speech of children of differing ages. Also, the use of EM might depend on the genre of a created text.

Aimed at discovering the development order of epistemic expressions in Russian, our study covers the initial, early (\$3) and final, late (\$4) stages of the acquisition of epistemic modality, mainly focusing on the three following research areas:

- the sequence of appearance of semantic fields (certainty vs. uncertainty) within epistemic modality;

- linguistic forms of their expression, i.e. such EM as parenthetical modal words and sentential complement constructions (or, in other terms, reduced and non-reduced modus frames); and

- functions performed at both utterance level and text level, not only in oral speech, but also in written texts.

The reasoning for our choice of these ages is explained by the fact that using the analysis of early adult-child dyadic interaction allows us: a) to reveal the time in which the first EM emerge in CS and to evaluate their frequency, i.e. to define the epistemic density of early dialogue speech (\$3.1); b) to identify the initial semantic and formal repertoire of EM, taking into consideration the degree of modal strength of epistemic semantics, and its development (\$\$3.2, 3.6); c) to define the first illocutionary types of utterances epistemically marked (\$3.3); d) to define the sequence of epistemic marking of core propositions (\$3.5); and e) to describe the functions with which EM begin to be used in CS (\$3.4).

The involvement of narratives created by schoolchildren, viz. younger (\$4.1) and older (\$4.2) adolescents, allows observation of the situation of using EM and - more widely - other subjective markers 
of the speaker's/writer's point of view (i.e. other modus devices) in new communicative settings, as well as assessment of the awareness of their choice. Particularly using the adolescents' data makes it possible to: a) evaluate the size of narratives and their epistemic density; b) describe the repertoire of epistemic and other devices of subjective attitudes; c) trace its development; d) consider the functional repertoire of parenthetical tools; and e) compare the functioning of EM in both spoken and written language, as well as in different genres. Thus, taking into consideration the new communicative settings requires the expansion of the score of dimensions and inclusion of a broad range of the language devices of subjective attitudes. At the same time, all the above-mentioned parameters of our analysis of EM in early adult-child dialogue, such as the degree of modal strength of epistemic semantics etc., are applied.

\section{Data and method}

For the first part of our study, which focuses on early CS, the duration of the longitudinal audio and video recordings analyzed was about 249 hours. They contain 245695 utterances from adult-child dyads (see Table 1 below). The recordings were transcribed and coded morphologically according to CHILDES (MacWhinney 2000) ${ }^{2}$.

For the second part of the study, which concerned later language development, more than 350 narratives written in the classroom by younger and older groups of adolescents were analyzed (see Table 1). The written texts were essays of three genres - an argumentation (on a controversial, problematic topic), a description (a picture of a historical topic, a photo, and a portrait were suggested as the objects), and a narration (based on life experiences). This data was supplemented by examples from 145 transcribed oral monologues from both groups of adolescents.

\footnotetext{
2 I am very grateful to T. Pranova, K. Bayda, M. Eliseeva, M. Voejkova, I. Jakovleva, N. Gagarina, E. Oficerova, E. Limbax, and M. Akkuzina for collecting these corpora and/or making them available.
} 
Table I. Russian data under investigation

\begin{tabular}{|c|c|c|c|}
\hline Group of subjects & Age (average) & Gender & Language samples \\
\hline $\begin{array}{l}\text { Children } \\
(\mathrm{N}=7)\end{array}$ & $\mathrm{I} ; 5-6 ; 5$ & $\begin{array}{l}\mathrm{N} \text { of females }=3 \\
\mathrm{~N} \text { of males }=4\end{array}$ & $\begin{array}{l}99542 \text { utterances } \\
\text { of CS }\end{array}$ \\
\hline $\begin{array}{l}\text { Adolescents (younger) } \\
(\mathrm{N}=30)\end{array}$ & $|4 ; 0-15 ; 1|$ & $\begin{array}{l}\mathrm{N} \text { of females }=14 \\
\mathrm{~N} \text { of males }=16\end{array}$ & $\begin{array}{l}\text { I } 80 \text { essays } \\
\text { (I } 570 \text { utterances), } \\
75 \text { oral monologues } \\
\text { ( } 743 \text { utterances) }\end{array}$ \\
\hline $\begin{array}{l}\text { Adolescents (older) } \\
(\mathrm{N}=30)\end{array}$ & $16 ; 0-17 ; 11$ & $\begin{array}{l}N \text { of females }=17 \\
N \text { of males }=13\end{array}$ & $\begin{array}{l}\text { I } 80 \text { essays } \\
\text { ( } 4590 \text { utterances), } \\
70 \text { oral monologues } \\
\text { (693 utterances) }\end{array}$ \\
\hline
\end{tabular}

The introspective statements of adolescents about how often they use parenthetical modal words and how much these words are needed in "textbooks of the future" (Kazakovskaya, Gavrilova 2019), together with relevant observations on EM in adult-directed speech (ADS) based on the Russian National Corpus (Kazakovskaya, Argus 2016; Kazakovskaya, Onipenko, in press) were also taken into consideration $^{3}$.

The data analysis took into account the following EM:

1) parenthetical modal words: naverno(e) 'probably', vidimo 'apparently', po-vidimomu 'apparently, appear to, seemingly', po vsej vidimosti 'possibly', verojatno and po vsej verojatnosti '(very) likely, probably', vozmožno 'perhaps, possibly', očevidno 'obviously', kažetsja 'it seems', požaluj 'very likely, perhaps, it may be', možet (byt') and byt' možet 'maybe', dolžno byt' 'probably', po-moemu 'in my opinion' for uncertainty, and konečno 'of course', dejstvitel'no 'really', na samom dele 'actually', pravda 'truly' lit. 'truth', (samo soboj) razumeetsja 'it goes without saying', bezuslovno 'certainly, sure', bessporno 'undoubtedly, undeniably',

\footnotetext{
3 The correlations between using EM and age, gender, SES, school performance level, etc. in the data of adolescents are under investigation; their discussion is the topic of our future paper (in preparation).
} 
nesomnenno 'certainly', and navernjaka 'without fail' for certainty. These epistemic devices are considered against the wide background of other parenthetical words which express emotional (e.g. $k$ sčastju 'fortunately'), textual (e.g. vo-pervyx 'firstly', naprimer 'for example'), authorship (e.g. po ego slovam 'according to him') semantics (Vinogradov 1947, Švedova 2005) used by the adolescents in their narratives (that is, other reduced modus frames);

2) sentential complement constructions with mental and speech verbs like I dumaju/sčitaju, (čto) p 'I think/believe (that) $p^{\prime}$ (non-reduced modus frames).

Since epistemic marking is characteristic of native speakers' speech to varying degrees, the frequency of EM use by different subjects was estimated using the epistemic density index. It represents the ratio of epistemically-marked utterances to the total number of utterances in the corresponding data.

\section{Emergence of EM in adult-child dialogue}

\section{I. EPISTEMIC DENSITY OF EARLY DIALOGUE SPEECH}

The first EM emerge during the third year of life - from 2;1 (according to diary observations (Kazakovskaya 2019), even from 1;9) to $2 ; 8$ - and already at this time their use is typical for different children to varying degrees. The highest index of epistemic density was possessed by one of the later-in-time data collection corpora (2010s, "Kirill"), the lowest by the earliest one (1990s, "Filipp"). Table 2 below shows the number of epistemically-marked utterances, the total number of utterances analyzed, and the epistemic density index for each corpus from middle SES families ${ }^{5}$.

EM in CS of Filipp and Liza are discussed in Kazakovskaya, Argus (2016).

The family of one girl belongs to low SES. EM were not documented in her speech (666 utterances) (Kazakovskaya 2017). 
Table 2. Epistemic density of early corpora

\begin{tabular}{|l|c|c|c|c|c|c|}
\hline \multirow{2}{*}{$\begin{array}{c}\text { Subject } \\
\text { (gender) }\end{array}$} & \multicolumn{3}{|c|}{ CS } & \multicolumn{3}{c|}{ CDS } \\
\cline { 2 - 7 } & $\begin{array}{c}\text { Utterances } \\
\text { with EM }\end{array}$ & $\begin{array}{c}\text { Total } \\
\text { number of } \\
\text { utterances }\end{array}$ & $\begin{array}{c}\text { Epistemic } \\
\text { density } \\
\text { index }\end{array}$ & $\begin{array}{c}\text { Utterances } \\
\text { with EM }\end{array}$ & $\begin{array}{c}\text { Total } \\
\text { number of } \\
\text { utterances }\end{array}$ & $\begin{array}{c}\text { Epistemic } \\
\text { density } \\
\text { index }\end{array}$ \\
\hline Vanja (m) & 184 & 53505 & 0.3 & 536 & 73047 & 0.7 \\
\hline Toma (f) & 30 & $1246 \mathrm{I}$ & 0.2 & 317 & 20499 & 1.5 \\
\hline Liza (f) & 34 & 9277 & 0.4 & 291 & 17506 & 1.7 \\
\hline Vitja (m) & 21 & 10145 & 0.2 & 162 & 13093 & 1.2 \\
\hline Filipp (m) & 13 & 8546 & 0.15 & 71 & 13009 & 0.5 \\
\hline Kirill (m) & 112 & 4753 & 2.4 & 337 & 6702 & 5.0 \\
\hline Total & 394 & 98687 & & 1714 & 143856 & \\
\hline
\end{tabular}

Despite the different sizes of the corpora (still taken into account completely due to the non-triviality of the phenomenon discussed), it seems that the size of the epistemic lexicon (and in a certain sense its diversity) in CS does not depend on the amount of data. Thus, the representative of the largest corpus (Vanja) does not have the most diverse epistemic repertoire. His epistemic lexicon contains 5 lemmas (that is, the same number as in Filipp's corpus, the smallest in terms of the number of corresponding tokens), while Kirill (the smallest corpus in terms of the duration of recordings and size) has 9 EM (see Table 3).

Table 3. The number of EM in CS and CDS

\begin{tabular}{|l|c|c|c|c|}
\hline \multirow{2}{*}{} & \multicolumn{2}{|c|}{ CS } & \multicolumn{2}{c|}{ CDS } \\
\cline { 2 - 5 } & Lemmas & Tokens & Lemmas & Tokens \\
\hline Vanja & 5 & 184 & 10 & 536 \\
\hline Liza & 7 & 34 & 9 & 291 \\
\hline Vitja & 6 & 21 & 8 & 162 \\
\hline Filipp & 5 & 13 & 6 & 71 \\
\hline Kirill & 9 & 112 & 12 & 337 \\
\hline Toma & 6 & 30 & 9 & 317 \\
\hline Total & & 394 & & 1714 \\
\hline
\end{tabular}


At the same time, according to the number of EM tokens, the highest indicators are those of Kirill (112) and Vanja (184), which, in turn, differ significantly in the volume of data (by almost 12 times): as mentioned, Kirill's corpus is the smallest, and Vanja's is the largest. On average, the epistemic repertoire of a modern Russian-speaking child from a family of middle SES is 6 lemmas, while a caregiver communicating with them has 9 (for both subjects $\mathrm{SD}=2$ ).

In the first month of EM emergence their number was small (1-2 lemmas), and the frequency of their use during the session was low (1-3 tokens). Two EM were noted in CS of the 2 children who had the most diverse epistemic repertoire by the end of observation: navernoe 'probably', po-moemu 'in my opinion' (Liza); navernoe 'probably', možet 'may' (Kirill). The main epistemic lexicon is intensively formed during the first year of the emergence of EM in CS. It is represented by 4 uncertainty markers: navernoe 'probably', možet byt' 'maybe', po-moemu 'in my opinion', kažetsja 'it seems', and their colloquial variants: naverno 'probably', možet 'may'. Later, after 4;6, the repertoire is updated very slightly, with 2 EM: vidimo 'apparently', vozmožno 'perhaps'.

\subsection{FROM UNCERTAINTY TO CERTAINTY}

The order of acquisition of EM consists of moving from explicit uncertainty to certainty. A similar sequence was documented in typologically different Estonian and Hebrew (Kazakovskaya, Argus 2016; Kazakovskaya et al. 2018). However, there is also data from several languages (including non-European ones) demonstrating acquisition in the opposite direction (Choi 2006; Matsui 2014; Hickmann, Bassano 2016).

The first EM which occurred in CS had a high degree of modal strength of epistemic semantics, on the one hand, and were the most frequent in CDS - on the other. So, within uncertainty this was navernoe 'probably' (1), within certainty - konečno 'of course' (2): 
(1) 2;8 Vanja: eto takoj volk, navernoe.

'it is kind of a wolf probably';

(2) 2;2 Liza: eto tramvaj, konečno.

'it is a tram of course'.

The further order of EM emergence within each field reflects such a system-language feature of epistemic modality as the graduality (or continuity) of semantics (e.g. Palmer 2001). Thus, the acquisition of uncertainty markers is a movement from navernoe 'probably' with a high degree of modal strength to kažetsja '(it) seems' with a low one (Kazakovskaya, Argus 2016). The certainty marking begins to develop from konečno 'of course' with a high degree to pravda 'truly' lit. 'truth' with a low one. EM of both semantic fields with a medium degree of modal strength (možet byt' 'maybe', po-moemu 'in my opinion'; dejstvitel'no 'really', na samom dele 'actually') occupy the middle position on this gradual scale. At the same time, the graduality of epistemic semantics correlates with the frequency of the corresponding EM: so-called high degree lemmas are used more often (Kazakovskaya 2017).

EM of uncertainty prevail in both diversity (lemmas) and frequency (tokens) in a dialogue at all ages from the third year of life to the seventh. They made up $84 \%$ of the epistemic data of our cumulative corpus. The ratio of the use of certainty and uncertainty markers in CDS at all stages has the same trend. Thus, EM of uncertainty prevail in the data analyzed as a whole (66\%). ${ }^{6} \mathrm{EM}$ of certainty are less diverse and numerous. Their repertoire increases more slowly, and their frequency decreases more clearly. This decline is particularly noticeable in the comparison of age-related stages. Thus, if the use of EM in the sphere of uncertainty is halved (from 38\% to 19\%), in the sphere of certainty it becomes three times less frequent (from $31 \%$ to $10 \%)$. In general, however, the frequency of epistemic marking

\footnotetext{
6 The ratio of certainty and uncertainty EM in ADS is almost the same: $51 \%$ vs. $49 \%$ (Kazakovskaya, Argus 2016).
} 
propositions does not decrease. Epistemic balance is preserved due to the emergence of new means of expressing this semantics, for which a child already has appropriate grammatical skills. In particular, the technique of using complex syntactic constructions, viz. sentential complement constructions like Ja dumaju, (čto) p 'I think (that) p', is developing. Modal particles (e.g. vrode by '(it) seems, seemingly, it looks as if', kak budto 'apparently, it would seem'), and secondary predication tools (see example 41 below), which can serve to express this semantics, also appear.

There are correlations between the frequency of explicit certainty and uncertainty in CS and CDS. They are found in the frequency of EM ( $r=0.93, p<0.001$ for tokens) and their lexical diversity $(r=0.73$, $\mathrm{p}<0.01$ for lemmas). The fact that the correlation is significant in both cases suggests that the more often a caregiver uses epistemic marking tools in their utterances and the more diverse EM are, the more likely they are to appear in CS and, consequently, the richer the child's repertoire is.

\subsection{FROM EM IN STATEMENTS TO INTERROGATIVES}

Early EM were documented mainly in non-interrogative utterances (viz. statements) related to the present situations 'here and now' (see examples 1, 2 above) and to the situations related to the past time (3). The epistemic assessment of judgments about future events develops later (4):

(3) 2;1 Filipp: naverno, papa.

'probably my dad [said about his father, who gave him a toy]';

(4) 3;2 Vanja: my, navernoe, na nego ${ }^{* 7}$ potom pokataemsja. 'we, probably, will ride on it ${ }^{\star}$ later'.

7 Hereafter the asterisk “*” will be used for marking child's errors. 
Within turn-taking at first, the epistemically marked statements occupy the reactive position (1-5), then such utterances begin to be used in the initiative position (6). The ability to use EM in interrogatives develops later (7):

(5) 2;5 Mother: Kirill, xočeš, počitajem knižku? 'Kirill, do you want to read a book?'

Kirill: $\quad$ da, konečno. 'yes, of course';

(6) 2;7 Vitja: vot pečka, po-moemu. 'here is a stove, in my opinion [said about one of the Christmas decorations, which he is sorting with his mother]';

(7) 3;4 Vanja: a možet, ja tebe kuplju caplju?

'maybe I should buy you a heron?'.

\subsection{FROM PRIMARY FUNCTIONS OF EM TO SECONDARY}

The development of EM functions in CS begins with their primary (basic) varieties. With their help the main epistemic semantics is implemented. That is, the statement is qualified in terms of certainty/uncertainty in the reliability of the reported (see examples 4 and 6 above). The development of secondary (non-basic) functions related to the actualization of a speaker's personality occurs later. This is evidenced by the diary observations of parents (9) on the speech of older children (Kazakovskaya 2019: 159-165). The most frequent secondary functions for EM are an underlining of the main modal evaluation (8), an explication of motivational relations (9), and logical inference (10):

(8) 4;2 Mother: ty čto, umeeš delat' volšebnye prevraščenija? 'can you do magic transformations?'

Kirill: konečno, mogu.

'of course, I can'; 
(9) 4;0 Ženja: dožd'-to včera ne pošel.

'it didn't rain yesterday'

verno, on pazdumal včera.

'probably, it changed its mind yesterday';

(10) 4;6 Mother: a ded na rabote zarazilsja, navernoe.

'and the grandpa was probably infected at work'

Toma: navernoe, kto-to zarall navernoe, kto-to zarazil ego.

'someone probably infec// someone probably

infected him'

Toma: $\quad$ čixnul prosto kto-to, navernoe.

'someone just probably sneezed'.

When EM are used in a secondary function, their basic - epistemic - semantics is complicated by additional nuances, including pragmatic (discourse) ${ }^{8}$. Such use implies a definite level of the child's communicative competence development.

\subsection{FROM THE OBJECTIVE TO THE SUBJECTIVE WORLD: EPISTEMIC MARKING OF CORE PROPOSITIONS}

In relation to which core propositions does a child need to express their certainty/uncertainty? This occurs mainly (about 70\%) in judgments about a physical situation, its components and participants - inanimate objects or surrounding realities'. Thus, the initial epistemic assessment is documented in the remarks about the presence/absence of objects (11), their nomination/identification (see examples 1-3 above), attributes - color (12), size, volume etc., actions and their circumstances - place (13), direction (14), time (4), and reason, etc.:

\footnotetext{
8 However, M. Krause, based on the results of experiments on "understanding of epistemic strength" by children, suggested that "early modal words fulfill, first of all, pragmatic functions of supporting speech interaction" and emphasized the need to collect longitudinal data that would allow the researcher "to judge the relationship between the production and understanding of modal markers by the same children" (2004: 138).

9 In comparison with the data of Estonian CS see (Kazakovskaya, Argus 2016).
} 
(11) 2;11 Vanja: o, bol'še, navernoe, doščeček netu.

'oh, there are probably no more planks left';

(12) 2;10 Vanja: Želtye ne byvajut, navernoe.

'there are probably no yellow ones [about cats]';

(13) 2;10 Vanja: a, oni, navernoe, na takoj poločke.

'oh, they are probably on a shelf like this';

(14) 2;11 Vitja: da, konečno, ono v tu storonu ne edet. 'yes, of course, it is not going that way'.

Judgments about animate subjects who do not participate in the conversation are epistemically marked less often and are not among the first ones:

(15) 2;9 Liza: $\quad$ da, eto deduška, navernoe, skazal.

'yes, my grandfather probably said that'.

After 3;0, a child proceeds to evaluate their own intentions, actions and circumstances of these actions (16), including those shared with a dialogue partner (17) or proposed to them (7):

(16) 3;3 Vanja: oj, navernoe, $v$ sadike ja ee poterjal.

'oh, I probably lost it at kindergarten';

(17) 3;0 Kirill: a možet, pokataemsja na "Leksuse" tuda-sjuda po-nastojaščemu? 'maybe we will go for a real ride back and forth in the Lexus?'

Such statements are less frequent (20\%), but they are nevertheless extremely important for cognitive development, since they show the development of the child's self-reflection. Finally, after 4;0, a dialogue partner becomes the object of the child's epistemic assessment - the partner's mental status (18), their controlled or uncontrolled mental activity (19): 
(18) 4;0 Vanja: $\quad$ ty, navernoe, znaješ, navernoe. 'you probably know, probably';

(19) 5;10 Kirill: mam, ty voob̌̌če ničego ne načala razdumyvat'sja*, ty, navernoe, zabylas'*. 'mom, you did not start thinking anything*, you probably forgot*'.

The emergence of such YOU-utterances (the subject of the evaluated proposition is the $2^{\text {nd }}$ person) can be interpreted as a child's awareness of the other's consciousness (Papafragou 2002: 185), that is, as the development of the 'child's theory of mind' and the modal language associated with it. During the analyzed period such utterances were rare (10\%). Their active usage, assuming an appropriate sociocognitive maturity, is a matter for future stages in the child's life.

\subsection{FROM PARENTHETICAL MODAL WORDS}

TO OTHER EPISTEMIC TOOLS

The first linguistic tools, which are functionally close to parenthetical modal words, since they are also able to reveal the speaker's point of view in CS, are sentential complement constructions like Ja dumaju/ sčitaju, (čto) p 'I think/believe (that) p' (20), Mne kažetsja, (čto) p 'It seems to me (that) $p$ ' (21). In other words, they are non-reduced mental modus frames (Kazakovskaya 2019: 166 for Russian CS):

(20) 2;10 Mother: kuda lučše (prizemlit'sja)?

'where is it better (to land)?'

Kirill: $\quad$ navernoe... navernoe, ja dumaju, čto lučše sjuda prizemlit'sja.

'probably... I think that it's probably better to land here';

(21) 3;0 Kirill: mne kažetsja, ploxo risuetsja.

'it seems to me it draws badly [about a pencil]'. 
Such constructions were documented in our data around $2 ; 6-3 ; 0$ years.

Thus, the results of the analysis of EM in early dialogue speech indicate that with the expanding categorization of reality, which is reflected in the development of the propositional content of a child's utterance, its epistemic assessment also expands. That is, the subjective (or modus) semantic sphere of the utterance develops gradually. The development of proposition attitude occurs in the direction going from the sphere of objective (physical) to the sphere of subjective (mental).

\section{The functioning of EM in the narratives of adolescents}

As the analysis of the schoolchildren's narratives of the two age groups has shown, the majority of adolescents use EM (and - more widely - other parenthetical words and modus devices) with a varying degree of frequency. There is an expansion in the semantic sphere of the subjective (or modus) judgments and in the schoolchildren's repertoire of linguistic forms of expressing it. Apart from EM of certainty/uncertainty, the following parenthetical components which also reveal the speaker and different facets of their subjective attitude were documented:

a) textual, or cohesive markers, reflecting the personality of the child as the creator of their own text (e.g. vo-pervyx 'firstly', naprimer 'for example', sledovatel'no 'consequently', takim obrazom 'thus'),

b) author's markers referring the judgement to themselves or another person as the author, and accordingly, revealing the source of information (e.g. po moemu mneniju 'in my opinion', po ego slovam 'according to him', po mysli Tolstogo 'according to Tolstoy's thought'),

c) emotional markers expressing their emotions (e.g. $k$ sčastju 'fortunately', $k$ sožaleniju 'unfortunately'). 
A new feature in the course of development is a more intensive inclusion of the other's point of view into the sphere of the epistemic attitude, which in turn leads to an increased complexity of 'the subject perspective' of the utterances and the text in general (Kazakovskaya, Onipenko in press), thus indicating the development of the discourse functions of EM. Let's look at the above-mentioned results in detail.

\section{I. THE NARRATIVE OF THE I4 AND I5-YEAR-OLD ADOLESCENTS}

The size of the written narratives of younger adolescents, or socalled early teens (cf. Berman 2017), comprised from 3 to 15 utterances. Thirteen p.c. (13\%) of them were epistemically and - more widely - subjectively marked. Nevertheless, EM were used neither by all adolescents, nor in all the texts.

Although the texts written by girls and boys did not differ in size (Table 4 below), the texts of the girls turned out to be twice as subjectively dense $\mathrm{e}^{10}$. Consequently, the epistemic density index was higher. The essays of the boys showed more uniform results regarding both their average size and the epistemic density index.

Table 4. The written narrative of the 14 and I5-year-old adolescents

\begin{tabular}{|l|c|c|c|c|}
\hline & $\begin{array}{c}\text { Text size } \\
\text { (average, in } \\
\text { utterances) }\end{array}$ & $\begin{array}{c}\mathrm{EM} \\
\text { (N in one text) }\end{array}$ & $\begin{array}{c}\text { Epistemic } \\
\text { density } \\
\text { index }\end{array}$ & $\begin{array}{c}\text { Preferred } \\
\text { linguistic forms }\end{array}$ \\
\hline Males & $\mathrm{M}=8.5, \mathrm{SD}=3$ & $\mathrm{M}=1.7, \mathrm{SD}=1$ & 9 & Parenthetical words (60\%) \\
\hline Females & $\mathrm{M}=9, \mathrm{SD}=6$ & $\mathrm{M}=2.3, \mathrm{SD}=2.3$ & 18 & Parenthetical words (72\%) \\
\hline
\end{tabular}

The parenthetical words, being the short form (the reduced modus frame) of expressing the semantics under discussion, dominated over the full form, represented by sentential complement constructions (having the full modus frame) in the narratives within each

\footnotetext{
10 Supposedly, this is related to the fact that females achieve better academically in this class.
} 
gender group. One can regard this as a transfer of an element characteristic of spoken (dialogical) speech into a written text.

We hold that the appearance of the new semantic group of parenthetical textual words, the share of which is almost equal to the share of EM ( $52 \%$ vs. $44 \%$ ), should be attributed to the pressure of written speech. The EM were represented by 3 lemmas of certainty (konečno 'of course', dejstvitel'no 'really', bezuslovno 'certainly') and uncertainty (očevidno 'obviously', možet (byt') 'maybe', vozmožno 'perhaps'), but the former were used more frequently (64\%):

(22) Takim obrazom, dejstvitel'no, verna mysl' o tom, čto žizn' bez Rodiny - eto ne žizn' (T.)

'Thus, really, true is the idea that a life without Motherland is no life'.

The emotional markers were missing, while the initial usage of author's markers (1 lemma) was documented (4\%):

(23) Ja soglasna s etoj myslju, potomu čto, po moemu mneniju, ni odin čelovek ne možet prožit’ bez svoej Rodiny (D.) 'I agree with this idea, because, in my opinion, no one can live without their Motherland'.

Sentential complement constructions with mental verbs (predominantly dumat' 'think' (67\%) and sčitat' 'believe') were typically used to express personal opinions (24) or agree with the author of a literary work discussed (25):

(24) Ja sčitaju, čto otvečat" "net" na etot vopros - glupo (N.)

'I believe, that answering "no" to this question is silly';

(25) Ja dumaju, čto avtor prav i bez Rodiny prožit' nikak nel'zja (D.) 'I think, that the author is right and one cannot live without Motherland'.

The early teens used linguistic forms expressing their subjective attitudes, revealing their point of view not only in argumentations (see above 22-25), but also in descriptions. The creation of written and 
oral (26-29) descriptions caused a more frequent use of means with the semantics of uncertainty. It was observed that the adolescents who demonstrate language-learning weaknesses used sentential complement constructions when creating oral descriptions as an instrument to help verbalize the thought when uttering and enunciating it. This was indicated by a slowed down tempo and noticeable pausation:

(26) Rebjata čto-to zapisyvajut// ja dumaju// [dlinnaja pauza] čto $z a$ učitelem (A.)

'The guys are jotting down something// I think / [a long pause] after their teacher'.

In narrations, full mental modus frames appeared to shape the concluding sentence (27), introduced the arguments for the state of affairs reported (28) or were accompanied by such (29):

(27) Ja staralsja pročitat' vse proizvedenija i vybrat' dlja sebja čto-to novoe/ takže... [dlinnaja pauza]// ja sčitaju/čto ja provel letnjuju poru spol'zoj (D.)

'I tried to read all the literary works and choose something new for myself/ also... [a long pause]// consider/ that I have spent the summer productively';

(28) Nekotorye [o rebjatax] v štanax// ja dumaju/ čtoby ne zagoret’ (A.)

'Some [about guys] are wearing pants// I think/ not to get tanned';

(29) Mogu predpoložit'/ čto sejčas solnečnyj den’/ tak kak na nix nadety kepki i panamki (A.)

'I can suppose/ that it is sunny now/ as they are wearing baseball caps and panama hats'.

In general, the characteristics of the use of EM and other parenthetical words in the written texts of the early teens correlated with the respective results of their oral narratives (see Kazakovskaya, Gavrilova 2018 for detail). The teenagers appeared in two roles: 
the author of the epistemic evaluation of the proposition and the author of their own text. In $18 \%$ of the epistemically-marked utterances a combination of markers was used and the modal semantics was complicated. As a rule, in such double marked utterances both markers belong to the writer ( $j a$ ' $I$ ', $1^{\text {st }}$ person) and reflect different facets of their point of view. That is, they are the egocentric elements (Padučeva 2017): see, e.g., dejstvitel'no 'really' and takim obrazom 'thus' in (22) above.

Most frequently, the object of the early teens' epistemic evaluation is some situation reflecting a fragment of objective reality or a judgement of the same. To a lesser extent the writer (the author of the text) epistemically evaluates their own judgement $(26,30)$ or the proposition that focuses on the other person, viz. their physical actions or mental states (31):

(30) Ja, konečno, ne svjazyvaju Rodinu s zakonami, ukladami ili pesnjami $<\ldots>$ (V.)

'I, of course, do not link the Motherland with laws, lifestyles or songs $<\ldots$..;

(31) I, vozmožno, každyj čelovek, priezžaja domoj, vspominaet, kak on ros, učilsja zdes' (D.)

'And, possibly, every person, coming home, remembers how they were growing up, studying here'.

Finally, linguistic devices conveying certainty were used to express agreement (or solidarization) with the opinion of the author of the literary work that was discussed in the essay:

(32) V konce koncov, možno utverždat', čto bez Rodiny žit' užasno (N.)

'All in all, one can claim, that life is terrible without the Motherland'. 


\subsection{THE NARRATIVE OF THE I6 AND I7-YEAR-OLD ADOLESCENTS}

The analysis of the written texts by high schoolers (i.e. late teens or older adolescents) showed an expansion in the size of texts, being from 16 to 34 utterances. The linguistic forms expressing different facets of a given older adolescent's point of view including EM were marked by $3-30 \%$ of utterances. That is, unlike the early teens, each writer used some means. In general, the marked utterances comprised $14 \%$ of all narratives.

Table 5. The written narrative of the 16 and 17-year-old adolescents

\begin{tabular}{|l|c|c|c|l|}
\hline & $\begin{array}{c}\text { Text size } \\
\text { (average, in } \\
\text { utterances) }\end{array}$ & $\begin{array}{c}\text { EM } \\
\text { (N in one } \\
\text { text) }\end{array}$ & $\begin{array}{c}\text { Epistemic } \\
\text { density } \\
\text { index }\end{array}$ & Preferred linguistic forms \\
\hline Males & $M=23, S D=6$ & $M=3, S D=2$ & 17.8 & Parenthetical words (87\%) \\
\hline Females & $M=28, S D=4$ & $M=2, S D=1$ & 10 & Parenthetical words (100\%) \\
\hline
\end{tabular}

As Table 5 shows, the texts of the males and females differed in size. The essays by the boys were shorter and more epistemically (and wider, subjectively) dense. The percentage of the epistemically and all subjectively marked utterances in their essays was twice as high as that in the essays of the girls. Expressing their point of view, the males mainly used the means of two modus fields (viz. those of mental and speech), placing them into the syntactic position of the matrix clause. The girls used more diverse modus semantics, employing emotional and author's evaluation, yet their preferred means of expression were exclusively parenthetical words. In comparison with the narratives of early teens, sentential complement constructions were used less frequently by the high schoolers.

EM reflecting the genesis of the argumentation of the speaker/ writer and their proposition attitude were a significant third of all the subjectively marked utterances. An increase of certainty EM is noted, which is due to the markers with a high degree of modal strength of epistemic semantics (na samom dele 'actually' (33), 
bessporno 'undoubtedly' (34)), which makes the field of certainty a dominant one ${ }^{11}$ :

(33) Na samom dele, eto zadanie - očen' trudnoe iskusstvo, kotoroe trebuet bol'šogo masterstva $(\mathrm{V}$.)

'Actually, this task is a very hard form of art that requires a lot of skill';

(34) Bessporno, $v$ dannom primere ispolnenie mečty, dejstvitel'no, prinosit čeloveku sčastje (A.)

'Undoubtedly, in this case a dream come true really makes one happy'.

The most frequently used markers turned out to be cohesive devices (viz. parenthetical textual words) marking the position of a statement in the linear sequence of a text and thus making it coherent, i.e. initiating it, structuring it, illustrating it by examples or ending it. They comprised 65\%:

(35) Vo-pervyx, pričina mesti dostatočno vesomaja <...>. Vo-vtoryx, vyzov na duel' - eto prjamoe zajavlenie o tom, čto vyzyvajuščij xočet ubit' vyzyvaemogo <...> (D.)

'First, there is a sound reason for revenge $<\ldots>$. Second, a challenge to a duel is an explicit statement of the fact that the one doing the challenging wants to kill the one being challenged $<\ldots$. ;

(36) Takim obrazom, garmonija $v$ otnošenijax otcov $i$ detej $v$ bol'šinstve slučaev vozmožna (A.)

'Thus, harmony in father-son-relationships is possible in the majority of cases'.

The cumulative share of the author's (37) and emotional (38) markers was modest (5\%). The use of the latter (expressing negative semantics and simultaneously a negative attitude) in the texts of the

\footnotetext{
3 There are no EM of low degree of modal strength and ones of medium degree are scarce.
} 
high schoolers indicated a new element in comparison with the narratives of the early teens:

(37) Po moemu mneniju, geroinja vybrala naibolee pravil'nyj postupok (O.)

'In my opinion, the main character chose the most appropriate thing to do';

(38) K sožaleniju, ne vse prodolžajut svoj žiznennyj put', delaja dobrye dela i prinosja radost' okružajuščim (A.)

'Unfortunately, not everyone keeps living their life, doing good things and bringing joy to others'.

Sentential complement constructions with mental ( $J a$ dumaju/ sčitaju, (čto) p 'I think/believe (that) p') and speech (Možno skazat', (čto) p 'One can say (that) $p$ ') verbs turned out to be less frequent in comparison to the corresponding parenthetical words. As a rule, they appeared in argumentations $(39,40)$. The uses of mental verb znat' 'know' (tending to be closer to the sphere of certainty) and speech verb skazat' 'say' implied a gradual amplification of the repertoire of the matrix verbs:

(39) Takim obrazom, možno skazat', čto blagorodnaja mest' v kakojto stepeni opravdyvaet posledstvija (D.)

'Thus, one can say that a noble revenge to some extent justifies the consequences';

(40) Ja dumaju, čto, možet, dannaja tematika podnimaetsja v pazličnyx proizvedenijax literatury (A.)

'I think, that maybe these issues are raised in different literary works'.

The ability to use a combination of these means within one statement (39-41), including ones that create so-called modal unison $(34,40)$, available even the youngest subjects, aged 14 to 15 years, is complicated by including the other's point of view within the perspective of the utterance and text (41). The share of the double marked utterances increases (20.5\%). 
(41) Naprimer, kogda ee syna i ego druzej zaderžali, ona, znaja, čto možet byt' zaderžannoj, otvažno prodolžila delo syna $<\ldots . .>(\mathrm{V}$.) 'For example, when her son and his friends were detained, she, knowing she could also be detained, courageously continued her son's actions $<\ldots .>$ '.

In the argumentations of the high schoolers, the function of solidarization with the author of the literary work remains, yet the repertoire of certainty markers is wider (nesomnenno 'certainly', razumeetsja 'it goes without saying'):

(42) Ja soglasna s poziciej avtora: razumeetsja, dannoe čuvstvo dolžno 'gret" serdca ljudej, nezavisimo ot togo, gde oni živut (O.)

'I agree with the author's point of view: it goes without saying, this emotion should 'warm up' people's hearts, regardless of where they live'.

EM of uncertainty are often used when forming a judgement of the protagonist's actions. One of the situations of evaluation is their ethical choice, which stems from an ethical error made earlier (43). A close function of EM was expressing a supposition regarding a shift in the protagonist's worldview (44):

(43) Obyčnyj voditel', kotoryj, navernoe, i ne zadumyvaetsja o svoej žizni, o svoem xaraktere, imenno vojna i dala emu etu vozmožnost' (M.)

'An ordinary driver [about the protagonist Andrey Sokolov in Šoloxov's 'Fate of Man'], who, probably, does not think at all about his life, his character, gets this opportunity because of the war';

(44) Možet byt', posle etogo ona priobrela opyt čelovečnosti $<\ldots>$ (I.) 'Maybe, after that she got her experience of being humane $<\ldots .$. '. At the same time, the degree of categoricity of the judgement varied. A lower degree of categoricity, expressed in the judgement of the protagonist's action, correlated with the degree of ethicality 
of expressing such judgements considered appropriate in the society (45), whereas a higher degree of categoricity went along with impersonal judgement (46):

(45) Navernoe, iz-za ravnodušija i neponimanija sledujut ssory, obidy $i$ daže razrušenija semej (A.)

'Probably, carelessness and misunderstanding cause arguments and even the destruction of families';

(46) No nužno li analizirovat' svoi ošibki? Bezuslovno, nužno (M.) 'But is one to analyze their own mistakes? This is certainly needed'.

The most complex discourse function of EM in texts is the reflection of different points of view. For this purpose, the parenthetical kazalos' by 'seemingly' was used, an infrequent form of representing the point of view and modality of seemingness in the high schoolers' narratives:

(47) Anna Alekseevna - semejnyj čelovek, kazalos' by, vse, čto nužno dlja žizni, u nee est' (Ye.)

'Anna Alekseevna is a family person, seemingly, she has all one needs for life'.

The rare uses of this marker can be attributed to its semantic and functional complexity. It belongs to the periphery of the given semantic field and fulfills secondary functions (Lekant 2002: 128). An opposition of points of view is evident. 'Someone' believes that the protagonist has everything for life, yet the author (Ye.) tries to demonstrate that this is only a seeming state of things, and the real state of things is different. Thus, rather cognitively complex semantic spheres are explicated, which are 'a declined supposition' and 'a dismissal of a fictitious notion'.

Finally, EM can perform the structural-organizing function, together with the conjunctions, e.g. no 'but' or odnako 'however' (in the same meaning), linking two clauses: 
(48) Vozmožno, etot slučaj individualen, odnako on proizvel na menja sil'noe vpečatlenie (M.)

'Perhaps, this case is unique, however, it impressed me a lot'.

Using EM in this new cohesive function implies creating contextual references between the clauses or parts of text even. This indicates an increase in the functional repertoire of parenthetical tools in the adolescents' narratives.

\section{Concluding remarks}

The study has shown the following characteristics of the development of epistemic modality and closely connected linguistic tools conveying subjective attitudes to the reported. The first EM appeared in the children's dialogue replies to express the semantics of uncertainty in the reliability of a given state of affairs. In the written narratives of adolescents, in turn, the EM of certainty dominated, whereas in ADS the quantity of both types levels out (Kazakovskaya, Argus 2016).

Parenthetical modal words, along with other types of parenthetical words, are a preferred form of explicating the speaker/writer's point of view both in early and later language development. The emergence of functionally similar sentential complement constructions containing mental and speech verbs in the matrix clause indicates an increase in the linguistic forms that serve to express epistemic modality, but does not change the proportion of the old (i.e., already used, learned) and new markers of epistemic (and in broader terms, subjective or modus) semantics. Sentential complement constructions do not become the dominant means of expressing this semantics by the end of the observation period. According to our preliminary observations, they are most frequently used by underachieving 14 and 15-year-olds in oral argumentation, being some kind of filler at the moment of formulation of thought and its voicing.

The system of linguistic forms referring to the speaker/writer develops from the explication of epistemic semantics to textual 
(cohesive) and - further - the author's (authorship) and emotional spheres. The formation of the early epistemic repertoire is defined by the degree of the modal strength of EM and their frequency in CDS. EM with a high degree were the first to be identified in CS. In the written narratives of the 14 and 15-year-olds, 6 EM were documented; in those of the 16 and 17-year-olds their number doubles. In both age groups of adolescents, EM of certainty dominated by the number of tokens. Both in early dialogue of children and in the later monologue of adolescents the repertoire of EM develops due to an increase of EM of a medium and a low degree of modal strength.

EM were not used by all children under investigation, and the epistemic density of their oral and written speech varied by age. In particular, in early dialogues, EM were absent in the speech of the child from a family of low SES (Kazakovskaya 2017); meanwhile, the underachieving adolescents did not use EM in their written essays, and one senior, who made many spelling mistakes in his form, suggested getting rid of them in "the textbook of the future" (Kazakovskaya, Gavrilova 2019). The average epistemic density index in the speech of children from middle SES families was 1.8. In the written corpus of the early teens it was 13 , and in the texts of the late teens it amounted to 14. It is significant that unlike the early teens, all the high schoolers epistemically marked utterances in their texts, although to different extents.

One can note preliminarily that the use of EM depends also on the genre of a written text: to a greater degree the emergence of EM is conditioned by argumentation, and to a smaller degree by narration. However, this observation needs to be further investigated. The appearance of EM in a text is also conditioned by the mental status of the speaker/writer, namely by the completeness/incompleteness of their knowledge, which was most salient when the adolescents were writing descriptive texts. A significant circumstance was the necessity to remain ethical in relation to the evaluated and/or rendered situation. 
The development of the functional range of EM was by an increase of functions and amplification of the sphere of their application. Thus, whereas early EM were used at the utterance (i.e., a dialogue reply) level in primary (epistemic per se) functions, later markers were used in secondary functions. In the written narratives of the adolescents, EM started functioning on the text level: they revealed an interplay of several points of view, i.e. a personal one, that of the author of the literary work and/or of the protagonist. They can be explained by reference to the socio-cognitive maturity and the definite level of the textual component of the communicative competence. Finally, the use of EM in the cohesive function reveals a speaking/writing teenager in the role of the author of their own text and reflects the process of building logical references between the components (or blocks) of narrative.

\section{REFERENCES}

Aksu-Koç, Ayhan 1988. The acquisition of aspect and modality: The case of past reference in Turkish. Cambridge: Cambridge University Press.

Arutjunova, Nina D. 1988. Types of linguistic meanings (assessment, event, fact). Moscow: Nauka (in RUS).

Bally, Charles 1965. Linguistique g.n.rale et linguistique fran.aise. Bern: Francke.

Berman Ruth A. 2017. Language Development and Literacy. - Encyclopedia of Adolescence, Levesque R. (ed.). Springer, Cham.

Berman, Ruth A. (ed.) 2004. Language development across childhood and adolescence. Trends in Language Acquisition Research (TILAR) 3. Amsterdam: John Benjamins.

Boye, Kasper 2016. The expression of epistemic modality. - The Oxford handbook of modality and mood. Eds. Nuyts, Jan; Auwera, Johan Van Der. Oxford: Oxford University Press, 117-140.

Bybee, Joann; Fleishman, Suzanne (eds.) 1995. Modality in grammar and discourse. Amsterdam: John Benjamins.

Choi, Soonja 2006. Acquisition of Modality. - The Expression of Modality, Ed. W. Frawley. Berlin: Mouton de Gruyter, 141-171. 
Gvozdev, Aleksandr N. 1949. The formation of the Russian grammatical system in the child. 2 vols. Moscow: Academy of Pedagogical Science of the Russian Federation Press (in RUS).

Hickmann, Maya; Bassano, Dominique 2016. Modality and Mood in First Language Acquisition. - The Oxford Handbook of Modality and Mood. Eds. Nuyts, Jan; Auwera, Johan Van Der. Oxford: Oxford University Press, 430-447.

Kazakovskaya, Victoria V. 2017. Language and cognitive aspects of the acquisition of epistemic modality. - Acta Linguistica Petropolitana 13, 3, 542-575 (in RUS).

Kazakovskaya, Victoria V. 2019. Questions and answers in adult-child dialogue: Psycholinguistic aspect. Moscow: Librokom (in RUS, summaries in ENG).

Kazakovskaya, Victoria V. in press. Epistemic modality in Russian child language. - Development of Modality in First Language Acquisition: A Cross-linguistic Perspective. Eds. Stephany, Ursula; Aksu-Ko., Ayhan. Berlin: Mouton de Gruyter.

Kazakovskaya, Victoria; Argus, Reili 2016. Acquisition of epistemic marking in Estonian and Russian. - Estonian Papers in Applied Linguistics 12, 57-80.

Kazakovskaya, Victoria V.; Argus, Reili; Uziel-Karl, Sigal 2018. The Early Expression of (Un)certainty in Typologically Different Languages: Evidence from Russian, Estonian and Hebrew. - Philologia Estonica 3, 93-130.

Kazakovskaya, Victoria V.; Gavrilova, Marina V. 2019. Parentheticality and teenagers (on the problem of point of view). - Problems of ontolinguistics 2019. Ivanovo: LISTOS, 389-397 (in RUS).

Kazakovskaya, Victoria V.; Onipenko, Nadežda K. in press. Grammar of the speaker's point of view: Parenthetical modal words in the speech of adults and children. - Problems of functional grammar: Relation to the speaker in the semantics of grammatical categories. Eds. Kazakovskaya, Victoria V., Voejkova, Maria D. Moscow: Jazyki slavjanskix kul'tur (in RUS).

Krauze, Marion 2004. Modal markers in child speech: Development of functions and system. - Children's speech as an object of linguistic research. Ed. Stella N. Ceitlin. St. Petersburg: Nauka, 136-139 (in RUS). 
Lekant, Pavel A. 2002. Essays on the grammar of the Russian language. Moscow: Moscow State Pedagogical University Press (in RUS).

Matsui, Tomoko 2014. Children's understanding of linguistic expressions of certainty and evidentiality. - Pragmatic development in first language acquisition. Ed. Danielle Matthews. Amsterdam: John Benjamins, 295316.

MacWhinney, Brain 2000. The CHILDES project. Tools for analyzing Talk. Electronic edition. Part 1: The CHAT transcription format.

Ovčinnikova, Irina G.; Uglanova, Inna A.; Krauze, Marion 1999. On estimation of the certainty/uncertainty degree of utterances by children of two age groups. - Problems of ontolinguistics 1999. Ed. Stella N. Ceitlin. St. Petersburg: Hertsen University Press, 132-133 (in RUS).

Padučeva, Elena V. 2017. Egocentric language items. - Materials for the project of the corpus description of Russian grammar. http://rusgram.ru. (in RUS).

Palmer, Frank R. 2001. Mood and modality. 2nd ed. Cambridge: Cambridge University Press.

Papafragou, Anna 2002. Modality and theory of mind: Perspectives from language development and autism. - Modality and its interaction with the verbal systems. Eds. Sjef Barbiers, Frits Beukema, Wim van der Wurff. Amsterdam, Philadelphia: John Benjamins, 105-204.

Reilly, Judi S.; Jisa, Harriet; Berman, Ruth A. 2002. Modal expression of propositional attitudes. - Written Languages and Literacy 5, 183-218.

Stephany, Ursula; Aksu-Koç, Ayhan (eds.) in print. Development of Modality in First Language Acquisition: A Cross-linguistic Perspective. Berlin: Mouton de Gruyter.

Stoljarova, Irina V. 1992. Expressing subjective and modal relations in child speech. - Child language: Linguistic aspect. Ed. Stella N. Ceitlin. St. Petersburg: Obrazovanie, 86-95 (in RUS).

Švec, Varvara M. 2007. Subjective (epistemic) modality and its expression in child speech. - Semantic categories in child speech. Ed. Stella N. Ceitlin. St. Petersburg: Nestor, 161-180 (in RUS).

Švedova, Natalia Yu. (ed.) 2005 (1980). Russian Grammar. Vol. 2. Moscow: Nauka (in RUS). 
Tomasello, Michael. 2003. Constructing a language: A usage-based theory of language acquisition. Cambridge, MA, London: Harvard University Press.

Vinogradov, Viktor V. 1947. Modal words and particles. - Vinogradov, Viktor V. Grammatical doctrine of the word. Moscow, Leningrad: Učpedgiz, 725-744 (in RUS).

\section{ABBREVIATIONS}

ADS adult-directed speech

CDS child-directed speech

CS child speech

EM epistemic markers

SES socio-economic status 
RESÜMEE

\section{EPISTEEMILINE MODAALSUS VENE KEELT OMANDAVATE VÄIKELASTE JA NOORTE KÕNES}

Artikkel põhineb osaliselt spontaanse kõne lindistustel, lisaks on kasutatud kirjalikke materjale. Artiklis on vaatluse all episteemilise modaalsuse kui leksikaalsemantilise kategooria omandamine. Vaatluse all on tõsikindluse ja ebatõenäosuse tähendusväljale kuuluvad episteemilise modaalsuse markerid nagu navernoe 'võibolla', možet byt' 'võibolla', konečno 'muidugi', dejstvitel'no 'tõesti/tegelikult' ning episteemilised osalaused nagu $I$ dumaju/sčitaju, (čto) p 'Ma arvan/mõtlen, (et) p'). Uurimuses on esitatud hulk omandamisega seotud eri tüüpi järjestusi; semantilised järjestused (nt alates deontilisest modaalsusest kuni episteemiliseni, eksplitsiitsest ebatõenäosusest kuni tõsikindluseni, ning hiljem episteemilisest kuni emotsionaalse hinnanguni); episteemilisuse väljendamise repertuaar (nt episteemilistest markeritest kuni episteemiliste, mentaalseid verbe sisaldavate osalausete ja kõneviisivormideni); episteemilise modaalsuse markerite funktsioonide järjestused (nt esmastest teise tasandi omadeni, lausetasandi markeritest testi tasandi omadeni). Samuti on vaatluse all episteemilise modaalsuse väljendusvahendite omandamisjärjekord. Tulemustest selgus, et kui varased episteemilise modaalsuse markerid olid kasutusel nende primaarses (episteemilises) funktsioonis, täitsid hiljem omandatud markerid teisi funktsioone. Kirjalikes tekstides funktsioneerisid episteemilise modaalsuse markerid teksti tasandil, need näitasid kirjutaja eri vaatepunkte ning demonstreerisid kirjutaja oskust siduda narratiivi eri osi.

Võtmesõnad: tõsikindlus, tõenäosus, tõenäosushinnang, episteemilised markerid, varane ja hilisem keeleomandamine, suuline ja kirjalik keelekasutus, vene keel

Victoria Kazakovskaya is a linguist working on first language acquisition, functional grammar, cognitive linguistics.

victory805@mail.ru 